\title{
DISCOURSE ON ETHNIC DIVERSITY AND IDENTITIES IN A SOCIO-PHILOSOPHICAL PERSPECTIVE
}

\author{
Maksym Kolesnichenko ${ }^{1}$
}

\begin{abstract}
The article analyzes the discourse on an essence of such widespread phenomena in the contemporary world as ethnic diversity and identity. They are defined by the author as socio-cultural phenomena. Much attention is paid to the interaction of these phenomena and its impact on social development. It is emphasized that ethnic diversity, contributing to the preservation and development of ethno-cultural variety is a positive phenomenon in itself, can lead to the emergence of isolationist tendencies in the development of polyethnic societies. Such trends are to some extent inherent in identity too. However, in specific conditions, the functioning of civic, European, national, political-civic, spatial-territorial identity stimulates unification processes within certain administrative-territorial entities. Activities for compromise interaction of ethnic diversity and identities, as well as overcoming their negative effects on public relations are discussed. The article is based on the study of the achievements of foreign and Ukrainian researchers in the field of ethnic interaction and ethnicity in general.
\end{abstract}

Keywords: ethnicity, ethnic diversity, identity, sociocultural phenomenon, polyethnic social space, ethnopolitical management

\section{General remarks}

We propose to consider the problem identified in the title of this article in the following aspects: 1) ethnic diversity is a state of ethnic situation in a certain social space (administrative-territorial unit) where there are numerous actors who are in constant interactions; if we use the term "ethnic diversification", we mean a process; 2) identity is a socio-cultural phenomenon (this hypothesis tends to be defined as an axiom); 3) identity and ethnic diversity are in permanent interactions, creating certain challenges for each other and for social development; 4) skillful ethno-political management is an efficient tool for compromises in the interactions of both phenomena.

In accordance with the above aspects, we structure our presentation as follows: content of ethnic diversity; identity content; contexts of interaction of ethnic diversity and identity. Before we begin the discussion, we need to clarify the essence of two key phenomena: "ethnic diversity" and "identity".

\footnotetext{
${ }^{1}$ Institute for Genetic Heritage Research in Social Communications; National Pedagogical Dragomanov University. kmv@isgis.org.ua, https://orcid.org/0000-0001-7685-2662
} 


\section{Content of ethnic diversity}

Scientific research and practice of modus vivendi convincingly show that the contemporary world is extremely ethnically diversified. The importance of ethnicity as a universal phenomenon of social development is intensively actualized at the current stage of social dynamics at the regional and global levels. Today, ethnicity effects almost all sectors of social life: "Ethnicity is now seen as a major feature of the social structure, personal identity, transnational networks and political conflict across the world. It is seen by some as challenging existing social hierarchies and conceptions of citizenship", so the Centre for the Study of Ethnicity and Citizenship, University of Bristol [35].

This situation is connected, first of all, with the obvious fact that there are holders of various ethno-cultural traditions and customs in the structure of the population of many countries. For example, American researcher of ethnicity James Fearson, taking into account the communities that make up at least $1.0 \%$ of the population of a country, identified about 820 ethnic and ethno-religious groups in 160 countries [20]. Ethnic heterogeneity is inherent in all continents, and almost in all countries: the international GREG database (which records ethnic groups linked to a specific area) covers 929 ethnic groups, and the Atlas of the Worlds identified 1248 groups by the middle of the last century (ethnicities not tied to a specific place of residence (extraterritorial ethnicities) [2] were also included). The most ethnically diversified are the countries of the African continent: there are numerous nations and nationalities and thousands different tribes who speak thousands of languages; American countries also belong to countries with a high level of ethnic diversity, for example, in Canada there are about 200 ethnic groups [37]; Recently, the population of large European cities has been intensively diversified ethnically: Berlin, Amsterdam, Vienna, Paris, etc., where people from other countries make up a significant percentage of their population.

Issues of ethnic diversity are discussed by representatives of different branches of social knowledge: anthropologists, economists, ethnologists, culturologists, political scientists, sociologists, philosophers. We will focus our definition of "ethnic diversity" and clarify its nature and relationship with the phenomenon of identity and address the challenges caused by this interconnectedness. Note that ethnic diversity is logically to consider in the two perspectives (scientific approaches) most common in Western scientific discourse on ethnic issues: socio-economic and socio-cultural. In the context of our study, the sociocultural perspective seems to be a productive scientific basis for understanding ethnic diversity, as it provides an opportunity to build such a research model that incorporates both patterns of socio-anthropological longevity of the phenomenon and features of its socio-cultural dynamics. We believe that the interdisciplinary approach, so called Mode $2[11,16]$, increasingly used by Western researchers in the study of ethnic diversity allows to penetrate deeper into the essence of the phenomenon and adequately, especially in specific socio-political conditions, to reproduce its content.

In their interpretations of the phenomenon of ethnic diversity, researchers are based primarily on the fact that in one state there are representatives of different peoples and cultures, usually united in a communities on the ethnic 
origin of their members [4, p. 278], who consider themselves part of the ethnos from which they come [41]. By the way, we will keep in mind that ethnic diversity tends to deepen at the local, regional, national levels, as well as in the international (interstate) dimensions. In this context, let us pay attention to the proposal of the American anthropologist Fred Riggs to use the term "ethnic diversity" in a narrow and in a broad sense. In the first case, according to F. Riggs, first of all it is about the fact that in conditions of tensions in relations between members of different ethnic communities, there are no conflict situations that split society along ethnic lines [30].

Thus, let us return to perhaps the most acute discussion in the context of understanding of ethnic diversity - its consequences for the social development of countries with polyethnic composition of their populations [4, p. 189-191]. In this discussion, two poles were formed: on the first, based on the analysis of accumulated data and facts, models of positive evaluation are formed; on the second - a negative assessment of ethnic diversity. These issues are discussed by Merlin Schaeffer, a researcher on the functioning of the phenomenon of ethno-diversity, in context of immigration [32] and by others concerning concrete social issues, for example education [31].

The basic point in assessing the impact of ethnic diversity is not only to establish differences (ethno-cultural, behavioral), but also how it manifests itself in the interaction of one group with another, as well as how it functions in a broad social space, including interaction with such phenomena as identity and social cohesion in a polyethnic society. To some extent, these approaches in the Ukrainian socio-humanities were considered in the context of the analysis of the concepts of ethno-social development of the United States and Canada [7]. It was: a) about the "dissolution" of a particular ethnic community (group) in a broader ethno-social context, or assimilation by one group (with a more stable ethnic field) to another (with a less powerful force of an ethno-field [4, p. 118]); b) the origin and consequences of various kinds of inequalities among ethnic groups; c) about the processes of mobilization and solidarity of actions, due to which members of ethnic communities sought to use their ethnicity in competition with other communities.

In the context of our analysis, it is necessary to take into account the sources of ethnic diversity. The vast majority of researchers associate the dynamics of the latter in a particular case of a state, primarily with migration. By the way, this tradition has developed for a long time, apparently under the influence of powerful migration processes, as well as the fact that ethnic problems have intensified in countries where immigrants play a significant role - in the United States and Canada. We pay attention to a wider range of sources for the formation of ethnic diversity, or polyethnicity. Analysis of facts, events, and scientific literature indicates that ethnic communities in a country emerged as a result of the existence of aboriginal (indigenous) populations, immigration, wars of conquest, and postwar division of territories [39]. As a result of the interaction of different components, new types of ethnic communities are formed (members of which often have hybrid characteristics [22]), new types of communication ties appear, which are a reproduction of the dynamics of ethnic diversification. At the same time new challenges appear, for instance concerning preservation of ethnic cultures [38]. 


\section{Identity content}

Let us try to present the main point of socio-philosophical discourse on basic parameters and contents of the phenomenon of identity as an important constructive element of the functioning of a community, which will help to reveal its social significance in general and in relation to its connection with ethnic diversity (polyethnicity).

In the context of determining the basic parameters of scientific discourse and the desire to deploy it, we should, in our opinion, first of all turn to those mobilizers of discourse, who, in fact, laid its foundations. Among these, we propose to turn to René Descartes, who with his statement "Cogito, ergo sum - I think, therefore, I am" [15] initiated a discourse around the question of identity which was dynamically continued later. It was facilitated by the transnationalization of ethnicities in the conditions of intensification of the development of network societies.

With regard to the definition and semantic content of the concept of "identity", especially with regard to the use of the term of the same name to describe the phenomenon in its contemporary interpretations, it is worth mentioning the work in this area by psychologist Erik Erikson (1902-1994). In his interpretations of the concept of "identity", the scientist tended to present it as a psycho-social identity [19]. However, the American social psychologist Roy Baumeister, draws attention to the fact that scientists have previously looked for answers to the question "what is identity?" [24]. In the search for the historical roots of the origin and development of identity theory, we cannot ignore the names George Mead. And Sheldon Stryker and Peter J. Burk [34], who focuses on the process of identity formation in the context of individual interaction, which has been called "identity negotiation" [36]. The latter is especially important when it comes to ethnic diversity, ethnic interaction, (interaction of different ethnicities), and in the analysis of the role of identity in a polyethnic society, these "negotiations" become almost the key to compromise and social cohesion [12, 25, 32].

In our context, we will list several names of researchers of the phenomenon of identity, whose works have intensified scientific discourse: Dominic Abrams, Zygmunt Bauman, William Bloom, Harrison White, Peter Berger, Alexander Wendt, Francis Deng, Legro Jeffrey, Peter Katzenstein, James Clifford, Paul Kower, Thomas Luckmann, James Marcia, Anthony Smith, Charles Taylor, Gary Herrigel, Michael Hogg, Stuart Hall and other foreign scholars. The range of issues of identity in their researches is from the origins of its formation to theoretical generalizations and its role in the development of various social formations, including the polyethnic composition of the population. In the works of Ukrainian researchers (Yevhen Bystrytsky, Bohdanna Hvozdetska, Maksym Kolesnichenko, Larysa Nagorna, Anatoliy Ruchka, Mykhailo Stepyko, Volodymyr Troshchynsky, Natalia Yakovenko, Volodymyr Yevtukh, [6, p. 140145] and others) the focus is mainly on the formation and functioning of identity in the Ukrainian social space and to some extent its place in the global world [3, $9,10]$ and, importantly, identity and methodology of cognition [1].

In determining the foundations of the essence of the phenomenon of identity, it would be useful, in our opinion, to use the summarized by James Fierson classification of approaches of contemporary Western researchers to its inter- 
pretation. The main parameters of identity are determined as follows: Identity is "people's concepts of who they are, of what sort of people they are, and how they relate to others" (Michael Hogg and Dominic Abrams); "Identity is used ... to describe the way individuals and groups define themselves and are defined by others on the basis of race, ethnicity, religion, language, and culture" (Francis Deng); Identity "refers to the ways in which individuals and collectivities are distinguished in their social relations with other individuals and collectivities" (Richard Jenkins); "National identity describes that condition in which a mass of people have made the same identification with national symbols -have internalized the symbols of the nation..." (William Bloom); Identities are "relatively stable, role-specific understandings and expectations about self" (Alexander Wendt); "Social identities are sets of meanings that an actor attributes to itself while taking the perspective of others, that is, as a social object" (Alexander Wendt); "By social identity, I mean the desire for group distinction, dignity, and place within historically specific discourses (or frames of understanding) about the character, structure, and boundaries of the polity and the economy" (Gary Herrigel); "The term [identity] (by convention) references mutually constructed and evolving images of self and other" (Peter Katzenstein); "Identities are... prescriptive representations of political actors themselves and of their relationships to each other" (Paul Kowert and Jeffrey Legro); "My identity is defined by the commitments and identifications which provide the frame or horizon within which I can try to determine from case to case what is good, or valuable, or what ought to be done, or what I endorse or oppose" (Charles Taylor); "Yet what if identity is conceived not as a boundary to be maintained but as a nexus of relations and transactions actively engaging a subject?" (James Clifford); "Identity is any source of action not explicable from biophysical regularities, and to which observers can attribute meaning"(Harrison White); "Indeed, identity is objectively defined as location in a certain world and can be subjectively appropriated only along with that world. ... [A] coherent identity in-corporates within itself all the various internalized roles and attitudes." (Peter Berger and Thomas Luckmann); "Identity emerges as a kind of unsettled space, or an unresolved question in that space, between a number of intersecting discourses.... [Until recently, we have incorrectly thought that identity is] a kind of fixed point of thought and being, a ground of action... the logic of something like a 'true self.' ... [But] Identity is a process, identity is split. Identity is not a fixed point but an ambivalent point. Identity is also the relationship of the Other to oneself" (Stuart Hall) [21].

The attempts of the known Ukrainian scholar in the field of ethnicity Volodymyr Yevtukh to present the definition of the concept of "identity" (by the names of one or another type of its varieties) are productive for our research too. Actually, we are talking about names that are found in contemporary foreign and Ukrainian scientific discourses. There are more than thirty of them in V. Yevtukh's structuring. We do not aim to analyze the content of each of the types of identity, but for now we will single out those that resonate with our interpretation of identity as a socio-cultural construct and effect the dynamics of ethnic diversity: ambivalent identity, hybrid identity, civic identity, elitarian identity (identity of ethnic elites), ethnic identity, transethnic identity, European identity, competitive identity, multiidentity, national identity, "shifting" identity, political-civic identity, spatial-territorial identity, religious identity, 
segment identity, societal identity, socio-cultural identity, transnational identity [4, p. 155-157]. Of course, this list can be extended by adding, for example, such an identity as "sender identity (information)", which has recently spread intensively in cyberspace and identifies a person by his e-mail address [33].

So, since Erik Erikson started the contemporary scientific discourse around identity and defined, in his opinion and in the opinion of many followers of his theoretical paradigms, the methodology of clarifying the essence of the phenomenon, our desire to focus on his work is quite natural. In the context of our analysis, we are convinced of his desire to combine psychological characteristics with social aspects, which makes it possible to more widely cover the range of meanings of identity and present it in adequate both scientific and practical design, which allows to identify (form) basic parameters of correlation between ethnic diversity and identity. They are as follows: 1) understanding the meaning of the longevity of the phenomenon (known in the literature as ego-identity); 2) at the same time, each person plays a social role and thus connects himself with social identity. In fact, the latter helps a person to integrate into the social environment, without which a person cannot imagine his existence; 3 ) the process of identity transformation lasts almost throughout the life of the actor, because he is constantly faced with challenges to which he must respond.

Note that based on the key statements of E. Erikson about the essence of identity and its dynamics, the Canadian-American researcher James Marcia built a paradigm of identity status, the basic idea of which is that an individual's sense of personality is largely determined by study himself and the obligations he or she makes regarding the manifestation (action) of certain personal and social traits. In our case, the features that are inherent in the representatives of other ethnic communities, in fact, the position of the ethnic factor to "otherness" [26].

In the research of professor Volodymyr Yevtukh, the fact that in the list of identities we are mainly talking about the forms of their manifestation, their functionality in the social environment attracts attention. For example, ambivalent identity, competitive identity, "shifting" identity, symbolic identity and others. However, there are some (we call them species), the names of which reproduce their content: for example, hybrid identity, ethnic identity, European identity, political and civic identity, religious identity, socio-cultural identity etc. Penetration into their essence will make it possible to identify factors that effect the dynamics of the phenomenon of "identity" and will to some extent manage changes in the essence of the phenomenon, primarily through the influence on the formation of conditions for the functioning of an identity. This is especially important, in our opinion, in a polyethnic social space.

Given the characteristics that researchers identify and attribute to the phenomenon of identity, we can conclude that identity in the vast majority of studies is presented as a complex multifaceted socio-cultural phenomenon, which combines personal, social and cultural components. Because identity has become an integral part of social processes and in the interaction of various components of the structure of society that shape its ethnic diversity, it plays a significant role in forming certain situations in this relationship. In addition, among many other factors, encourages the definition of Western scholars types of identity, which, according to our observations, is based on socio-cultural fac- 
tors, say: gender, group, ethnic, cultural, professional, racial, religious, social, physical etc. identity [17]. However, despite the diversity of these markers, most researchers agree that in a broad sense, identity is inherent in all factors, whether the focus is on personality or social phenomena, it ultimately includes a sense of identity, longevity, and integrity [24].

Based on a set of certain markers, identity refers to a particular species; the latter (species) are listed by us above. Such markers are usually appearance, language, cultural traditions, customs, elements of behavior, manner of communication etc. In fact, the complexity and versatility of the phenomenon with an extremely diverse "portfolio" of characteristics and markers provide, according to Rogers Brubaker and Frederick Cooper, an opportunity for researchers to determine the identity simultaneously of both the practical category and the category of scientific analysis [14]. However, for all this diversity, almost all researchers study the phenomenon of identity within two major systems that combine the types of identities distinguished by researchers: the system of individual identities and the system of collective (group) identities. In the first case, the desire to determine the essence of identity, based on psychological (personal) factors prevails, and in the second, the tendency to think about the meaning of the concept of "identity" to promote social factors prevails. In general, since the holder of identity is a specific factor (a human-being), largely formed by the social environment, and even more its essence is manifested in this environment (in the process of interaction with their peers or different), then, in our opinion, in the context of finding the basic foundations of the study of the phenomenon of identity, the most generalized (umbrella) definition is "reproduction of perception (understanding) of oneself as a complex special being with certain social, cultural, ethnic markers" [4, p. 155]; we will add, force of influence on formation of certain situations which is shown in individual or group interaction. The process of formation of these situations is a permanent phenomenon, so the study of the essence, qualitative and quantitative characteristics of objects and subjects involved in these situations, is obviously an important element of continuing scientific discourse on a topic, in our case functioning identity in a polyethnic (ethnically diversified) social space.

\section{Contexts of interaction of ethnic diversity and identity}

Analysis of research by both foreign and Ukrainian scientists gives us reason to assume that two phenomena operate within the same problem field. The latter is formed under the influence of a number of factors, among which those related to ethnicity, in particular ethno-cultural and socio-political processes come to the fore. In this regard, two vectors of interaction between ethnic diversity and identity emerge: a) coincidence; b) conflictogenicity. In the first case, ethnic (ethno-cultural) identity, transethnic identity, national identity, religious identity, segmental identity, symbolic identity, socio-cultural identity, transnational identity, "shifting" identity, according to our observations, reinforce ethnic diversity; in the second - hybrid identity, civic identity, competitive identity, multiidentity, atomized (scattered) identity, political-civic identity, spatial-territorial identity, on the contrary, are a challenge for ethnic diversity, as they to some extent contribute to strengthening positions within small 
or large administrative-territorial units. The desire for separation, for isolation (which is a component of ethnic diversification) may conflict with the process of forming broader and to some extent more cohesive associations, the components of which may include representatives of different ethnicities, which, for example, form a civic, spatial-territorial, political-civic identity. Conflictogenicity in interaction is exacerbated by the presence of holders of hybrid identity, competitive identity, atomized (scattered) identity, multiidentity, because they, depending on the circumstances, can act both in favor of ethnic diversification and in favor of unifying processes. It is at these points that the Bristol Center statement cited above on the occasion of its decade on the role of ethnicity in the modern world is highlighted; by the way, ethnicity largely determines the functioning of diversity and identity.

The strength of one or another trend depends on the contexts of ethnic diversity and identity. Among a number of these contexts, the following are the most relevant: a) the current ethnic composition of the country's population (with a high degree of polyethnicity, the process of diversification intensifies; the tendency to establish those types of identities that "do not work" for solidarity processes that consolidate the cohesion of society becomes stronger); b) the prospects of migration processes of holders of a particular ethnicity both from the output country and to the input country, which leads to a change in the ethnic composition of the population and can be clearly felt especially at the regional level in ethnic areas and ethnic enclaves; c) state policies regarding ethno-national communities and population migration, for example, assimilationist concepts (they were inherent in certain periods of US history) contributed to the slowdown of ethnic diversity and trends towards multiculturalism, on the contrary, deepened it. In both cases, the question of finding compromises in order to avoid conflict situations in the development of polyethnic societies is relevant; in this sense, we are talking, first of all, about the skill of ethno-political management [4, p. 123-125].

\section{Instead of conclusions}

In understanding the interaction of ethnic diversity and identity, the question of the nature of social processes and culture, their relationship and interaction is gaining in importance. All this is due to the fact that the various elements of culture and traditions, the holders of which are people from different countries living within the same state, cause, objectively or subjectively, many problems, say, related to adaptation to each other, with the search for compromises in their conflict-free coexistence. Under these circumstances, in the regulation of the interaction of ethnic diversity and identities (and we can say the management of this interaction) an important element is the search for opportunities for such a settlement. In this sense, we are talking, first of all, about ethno-political management. Western researchers rightly point out that when the population is extremely ethnically, culturally and religiously diverse, it is undoubtedly a very difficult thing to achieve balance or consensus, forcing states to build different approaches to managing a multi-ethnic population. Today in foreign and Ukrainian socio-humanitarian science there are works that can form the basis for building effective ethno-political management in a specific ethno-political unit (state) [8, 18, 23, 27, 28, 29, 40]. 
We believe that the principles of the investigation of ethnic diversity based on the study of ethnic and cultural groups, which, in fact, with their identities and create ethnic diversity, proposed by the American social philosopher and specialist in multicultural education James Banks, need to be further developed, and this research methodology must be adapted to the theory and practices of the Ukrainian ethno-social and ethno-cultural contexts, in particular to the conflict-free interaction of ethnic diversity and identities. Here we are talking about some its components which are to be taken into consideration: origin and immigration (ethnic origin of the local population and ethnic and cultural groups of immigrant origin); common culture, values and symbols (this refers to the interaction of original (ethnic) cultures, values and symbols with such countries of residence); ethnic identity and the essence of the concept of "people" (focus should be on ethnic identity as a result of joint interaction history and contemporary experience); ethnic institutions and self-determination (functioning of ethnic organizations and their role in uniting ethnic communities); demographic, social, political and economic status (we are talking about ethnic dynamics and its relationship with the status of communities in the country of residence); prejudice, discrimination and racism (considered as the key point to understanding the experience of ethnic communities in the past, present and future); intra-ethnic diversification (concentration of attention on the factors of ethnic diversity that takes place in the community); assimilation and acculturation (these are changes that take place in the process of interaction between ethnic communities and representatives of the titular nation); influence on ethnic diversification, on ethnic communities of radical transformations taking place in the society of residence [13, p. 57].

We would like add to these points another two factors, in our mind very important and not studied at all: genetic and ethnic information in building both constructs - ethnic diversity and identity.

Theoretical research and political-managerial practices should be based on a socio-cultural perspective that most adequately corresponds to the essence of ethnic diversity and identity as socio-cultural phenomena.

\section{References}

[1] Bystrytskyi, Yevhen. 2013. Identychnist, spilnota i metodolohiia piznannia. Nezalezhnyi kulturolohichnyi chasopys «I». www.ji-magazine.lviv.ua/ anons2013/Bystryckyj_identychnist_spilnota.htm.

[2] Bruk, S. I. 1964. Atlas narodov mira. Moskva, Glavnoe upravlenie geodezii i kartografii Gosudarstvennogo geologicheskogo komiteta SSSR. $157 \mathrm{~s}$.

[3] Ievtukh, V. B. 2010. Vzaiemodiia Ukrainy z yevropeiskymy ta transatlantychnymy strukturamy u konteksti identychnostei Mizhnarodnyi naukovyi forum: sotsiolohiia, psykholohiia, pedahohika, menedzhment: zbirnyk naukovykh prats. Kyiv: Vyd-vo NPU im. M.P. Drahomanova, 3, 3-19.

[4] Ievtukh, Volodymyr. 2012. Etnichnist: entsyklopedychnyi dovidnyk. Kyiv, Feniks, 396 s.

[5] Ievtukh, Volodymyr. 2013. Etnichnist u transnatsionalnomu sotsialnomu prostori: dyzain doslidnytskoho proektu. Sotsiolohiia: teoriia, metody, marketynh. 1, 3-26. 
[6] Ievtukh, Volodymyr, Kolesnichenko Maksym. 2016. Fenomen etnichnosti u zarubizhnomu naukovomu dyskursi: filosofske osmyslennia. Kyiv. TOV «NVP «Interservis», $238 \mathrm{~s}$.

[7] Evtukh, V. B. 1991. Konczepczii etnosoczial'nogo razvitiya SShA i Kanady: tipologiya, tradiczii, evolyucziya. Kiyiv: Naukova dumka, $180 \mathrm{~s}$.

[8] Zan, M. P. 2020. Porivnialnyi analiz etnopolitychnoho menedzhmentu v Slovatskii Respublitsi ta Ukraini (za rezultatamy ekspertnoho opytuvannia). Naukovyi zhurnal «Politykus», 2, 177-184. http://politicus.od. ua/2_2020/26.pdf.

[9] Stepyko, M. T. 2020. Ukrainska identychnist u hlobalizovanomu sviti. Kharkiv: Maidan, $258 \mathrm{~s}$.

[10] Formuvannia ukrainskoi identychnosti v umovakh suchasnykh vyklykiv: teoretychni i politychni aspekty. 2018. Kyiv, NADU, $256 \mathrm{~s}$.

[11] Academic discipline. 2021. From Wikipedia, the free encyclopedia. https: //en.wikipedia.org/wiki/Academic_discipline.

[12] Achieving social cohesion in a multicultural Europe. 2006. Concepts, situation and development. Trends in social cohesion. № 18. Strasbourg: Council of Europe Publishing. 402 p.

[13] Banks, J. 2009. Teaching strategies for ethnic studies, 8th Edition. Chesterton Mill, Pearson Publishing, 544 p.

[14] Brubaker, Rogers and Cooper Frederick. 2000. Beyond "identity". Theory and Society, 29, 1-47. https://canvas.harvard.edu/files/3747718/download? download $\mathrm{frd}=1$.

[15] Cogito, ergo sum. 2021. From Wikipedia, the free encyclopedia. https: //en.wikipedia.org/wiki/Cogito,_ergo_sum.

[16] Cohen, E., Lloyd, S. 2014. Disciplinary evolution and the rise of the transdiscipline. Informing Science: the International Journal of an Emerging Transdiscipline. Vol. 17. Pp.18 9-215. http://www.inform.nu/Articles/ Vol17/ISJv17p189-215Cohen0702.pdf.

[17] Desmet, K., Ortu-Ortin Ignacio, Wacziarg Roman. Culture, ethnicity, diversity. https://www.anderson.ucla.edu/faculty_pages/romain.wacziarg/ downloads/2017_culture.pdf.

[18] Diversity in action. 2001. Local public management of multi-ethnic communities in Central and Eastern Europe / Edited by Anna-Mária Bíró and Petra Kovács. Budapest, Local Government and Public Service Reform Initiative, $390 \mathrm{p}$.

[19] Erikson, Erik H. 1968. Identity, youth and crisis. New York: W.W. Norton Company, 336 p.

[20] Fearon, J. 2003. Ethnic and cultural diversity by country. Journal of Economic Growth. 8(2), 195-222. http://www.jstor.org/stable/40215943.

[21] Fearson, James. 2013. What is identity (As we now use the word)? https://web.stanford.edu/group/fearon-research/cgi-bin/wordpress/wp-content/ uploads/2013/10/What-is-Identity-as-we-now-use-the-word-.pdf (2.12.2020).

[22] Holly, T.H. 2009. National identity: Civic, ethnic, hybrid and atomised individuals. Europe-Asia Studies, 61(1), 1-28.

[23] Houten, P. V., Wolff, S. 2018. The dynamics of ethnopolitical conflict management by international and regional organizations in Europe. https: //www.ecmi.de/fileadmin/doc/JEMIE_1-2008-van_Houten.pdf. 
[24] IDENTITY (Social Science). https://what-when-how.com/social-sciences/ identity-social-science/.

[25] Laurence, J. 2011. The effect of ethnic diversity and community disadvantage on social cohesion: A multi-level analysis of social capital and interethnic relations in UK communities. European Sociological Review. 271(1), 70-89.

[26] James, Marcia. Identity status (Marcia). https://www.learning-theories. com/identity-status-theory-marcia.html.

[27] Measuring identity: a guide for social scientists. 2009. / Ed. By Rawi Addelal, Yoshiko M. Herrera, Alastar Iain Johnson and Rose McDermott. New York: Cambridge University Press, VII, 428 p.

[28] Melançon, J. 2012. Multinationalism and polyethnicity in the Canadian philosophy of multiculturalism.

http://www.cpsa-acsp.ca/papers-2012/Melancon.pdf.

[29] Multiculturalism: A policy response to diversity. www.unesco.org/most/ sydpaper.htm.

[30] Riggs, F. 1998. The modernity of ethnic identity and conflict. International Political Science Review. 19(3), 269-288.

[31] Rubene, Zanda, Andersone Rudite, Yevtukh Volodymyr, Kisla Anna, Balode Maija, Shtepa Serhiy. 2019. Immigrants in society: Challenges for education in Ukraine and Latvia. International Journal of Smart Education and Urban Society (IJSEUS). 10(2), 70-77.

[32] Schaeffer, M. 2014. Ethnic diversity and social cohesion. Immigration, ethnic fractionalization and potentials for civic action.

http://ceemr.uw.edu.pl/vol-3-no-1-june-2014/book-reviews/merlin-schaeffer2014-ethnic-diversity-and-social-cohesion.

[33] Sender identity | SendGrid Documentation. https://sendgrid.com/docs/ for-developers/sending-email/sender-identity/.

[34] Stryker Sheldon and Peter J. Burke. 2000. The past, present and future of an identity theory. Social Psychology Quarterly. 63(4), 284-297. www. jstor.org/stable/2695840.

[35] Ten Years of Centre for the Study of Ethnicity and Citizenship, University of Bristol. https://www.bristol.ac.uk/medialibrary/sites/ethnicity/ migrated/documents/ethnicity10.pdf.

[36] Ting-Toomey, S. Identity negotiation theory. Sage Encyclopedia of International Competence. Volume 1. Los Angeles, CA: Sage, 418-422.

[37] Wolff, S. Ethnic minorities in Europe: The basic facts. www.stefanwolff. com/files/min-eu.pdf.

[38] Yevtukh, Volodymyr. 2018. Cultural security in ethnic diverse society: Challenges for Ukraine. Jagiellonian Ideas Towards the Challenges of Modern Time. Kraków, 249-279.

[39] Yevtukh, Volodymyr. 2016. Polyethnicity. The Willey Blackwell Encyclopedia of Race, Ethnicity and Nationalism. 1-3. http://onlinelibrary.wiley. com/doi/10.002/9781118663202.wberen579/full.

[40] Yevtukh, Volodymyr. 1995. Ukraine's ethnic minorities: Between politics and reality. The Harriman Review. 9(1-2), 62-64.

[41] Yevtukh, Volodymyr. 2018. Ukrainian ethnos as a complex socio-cultural phenomenon. Interdisciplinary Studies of Complex Systems. 13, 41-56. 